\title{
Europæisk asylpolitik og grænseskabt fordrivelse
}

Af Martin Lemberg-Pedersen

Humanitære organisationer har ofte kritiseret den europæiske grænsekontrol for at skabe et 'Fort Europa'. Nationalistiske partier og foreninger har omvendt og i stigende grad gennem 2015 argumenteret for nødvendigheden af at udbygge en sådan fortlignende grænsekontrol. Mens førstnævnte perspektiv er udledt fra humanitære principper, stammer sidstnævnte fra det indenrigspolitiske ønske om at undgå asylansøgere.

For at forstå hvordan EU's grænsekontrol fungerer, er det nødvendigt at se på den indenrigspolitiske situation i unionens medlemslande. Her har stigende nationalisme ført til en omdefinering af asylpolitik, der er gået fra at være et beskyttelsesværktøj til et afskrækkelsesredskab. Derved er også opmærksomheden på den udenrigspolitiske dimension i asylpolitikken blevet undermineret, og i det retsløse vakuum, der er skabt mellem staters afvisning af asylansøgere, er der opstået en speciel form for tvungen flygtningemobilitet; nemlig grænseskabt fordrivelse.
Denne artikel beskriver, hvordan denne form for fordrivelse først blev produceret uden for EU, og hvordan den i 2015 efter Syrien-konfliktens eskalering, Schengen-grænsernes kollaps og EU-medlemslandes spekulation i hegn- og transitpolitikker nu også kan observeres på Unionens eget territorium.

\section{Et 'Fort Europa'?}

Problemet med 'Fort Europa'-analogien er, at den fejlkarakteriserer EU's asylpolitik. Både fordi den underkender de beskyttelsesredskaber, som medlemslandene rent faktisk benytter sig af, men også fordi den antyder, at EU's grænsekontrol primært foregår ved at ophobe flygtningestrømme uden for hegn og mure.

Mens det er sandt, at vi har set en genopblomstring af hegn-teknologien, er denne langt fra karakteristisk for hele den europæiske grænsekontrol. Godt nok var de 6 meter høje hegn, der i 2006 blev bygget ved de spanske enklaver i Nordafrika, Ceuta og Melilla, medvirkende til den spontane opståen af uofficielle slumflygtningelejre i bjergene omkring de to byer.

Martin Lemberg-Pedersen er Post Doc ved Centre for Advanced Migration Studies, Københavns Universitet, hvor han i 2012 skrev sin ph.d. om EU's grænsekontrol. Han har udgivet artikler, bogkapitler og rapporter om EU's grænsekontrol og dens humanitære konsekvenser, dansk asylpolitik over for uledsagede mindreårige og dansk integrationspolitik. 
Men nøjagtig ligesom hegnene, som flere Balkanlande har bygget i 2015, har Ceuta og Melilla-hegnene først og fremmest den effekt at lede flygtningene videre mod andre grænseovergange. Det er altså ikke flygtninges immobilitet, der er den afgørende konsekvens af hegn-teknologien, men i stedet deres cirkulation videre til andre territorier og grænseovergange.

Unionens grænsekontrol inkluderer desuden også patruljer, satellitter, radar-netværk, droner, deportations-mekanismer og lejrsystemer. Dette komplekse system breder sig desuden på tværs af medlemslandenes nationale grænser blandt andet gennem virtuelle databaser som EURODAC og EUROSUR og gennem supranationale mekanismer som Frontex, EU's koordinerende grænseagentur, der sammenlægger medlemslandenes suveræne magtbeføjelser i operationer som Hera I-III, Seahorse, Poseidon, og Triton. Alle disse teknologier overvåger, indfanger, registrerer og cirkulerer flygtninge igennem et transnationalt netværk af grænsekontrol.

Denne cirkulation gælder i endnu større grad grænsekontrol-teknologien med deportationer, og indlysende også med transitpolitik. I 2015 har lande som Serbien, Kroatien og Danmark således, for at undgå at modtage asylansøgninger, ladet flygtninge rejse i transit gennem deres territorier. I efteråret 2015 førte dette til dramatik ved den kroatisk-ungarske grænse, da ungarsk politi måtte afvæbne kroatiske vagter i et tog, der bragte flygtninge ind på ungarsk territorium. Tilsvarende kritiserede Sverige også Danmark gentagne gange for at lade titusindvis af flygtninge køre over Øresundsbroen uden at registrere dem og åbne asylsager.

Disse forskellige cirkulations-dynamikker i europæisk grænsekontrol afslører, at analogien mellem hegn-politik og et 'Fort Europa' kun kan fungere, hvis man insisterer på at betragte medlemslandenes grænsepolitik som løsrevet fra hinanden. Hvis man med andre ord antager en metodisk nationalisme i ens analyse. Dette er dog yderst problematisk, idet flygtningestrømme og grænsekontrol begge er grænseoverskridende, transnationale fænomener, og en sådan analyse risikerer derfor at forbigå de åbenlyse konsekvenser som nabolandes grænsepolitik har for hinanden og for flygtninge. Og den lader også grænsernes overordnede funktionalitet for en supranational størrelse som EU ude af syne. I stedet for at sammenligne EU's grænsekontrol med et fort, bør unionens grænsesystem derfor anskues som et transnationalt netværk bestående af forskellige kontrol-teknologier, der påfører flygtninge forskellige ruter og forskellige former for mobilitet.

Hvis man betragter flygtningestrømme til EU op gennem 00'erne, ses denne dynamik: Tilbage i 2004 søgte de fleste flygtninge mod EU gennem den såkaldt vestlige Middelhavsrute, der førte til Spanien gennem de Kanariske Øer og Ceuta og Melilla. Efter at EU i 2005 søsatte de allerførste Frontex-operationer (Hera I-III) ved de Kanariske Øer og efter spanske og marokkanske styrkers nedskydninger af flygtninge ved hegnene i Ceuta og Melilla, forskubbedes flygtningestrømmene væk fra Spanien. Derved opstod den centrale Middelhavsrute fra Libyen til Lampedusa, Malta og det italienske fastland, og fra 2007 prøvede flygtninge især denne rute. Men i takt med at EU satte ind med Frontex-operationer ved denne rute, forrykkedes flygtningestrømmene imidlertid videre, og fra 2010 opstod den østlige Middelhavsrute gennem især Tyrkiet og Grækenland, selvom Grækenland også 
før dette var en af de største indgangsruter for bådflygtninge til Europa. Hvad denne forrykkelse af flygtningestrømme viser er, hvad Frontex selv har kaldt en 'fordrivelseseffekt' af dens egne operationer: Hvis de oprindelige årsager til folks behov for flugt og beskyttelse består, vil øget grænsekontrol ikke være en løsning, men højst en symptombehandling, der blot tvinger flygtninge mod andre og ofte mere farlige ruter.

Man kan derfor med rette spørge, hvorfor EU og medlemslandene op gennem 00'erne har fokuseret så meget på Frontex-operationer frem for de grundlæggende årsager til folks flugt. Én årsag er uden tvivl modvilje mod at ændre de dele af Unionens udenrigspolitik, der er medvirkende til fordrivelse såsom overfiskeri, handels- eller militærpolitik. Men gennem 00'erne blev det også klart, at for medlemslandenes del skyldtes det altoverskyggende fokus på grænsekontrol også $\mathrm{i}$ høj grad indenrigspolitiske hensyn.

\section{Indenrigspolitisk drejning}

Indenrigspolitik har i flere år haft en central rolle i udviklingen af EU's asylpolitik og grænsekontrol. Dette har ikke altid været tilfældet, da det i midtfirserne især var transport- og udenrigsministre fra medlemslandene, der stod for udformningen af unionens grænsepolitik. Op til Dublinkonventionens indførelse i 1990 skete der dog noget: Justits - og indenrigsministre (senere Rådet for Indre og Retslige Anliggender (RIA)), og deres embedsværk, overtog førertrøjen i politikudviklingen.

Op gennem 00'erne forstærkedes dette indenrigspolitiske perspektiv yderligere via udviklinger i de enkelte medlemslande. Sideløbende med en bred EU-skepsis blev grænsekontrol og eksklusion af asylansøgere populære mærkesager for nyere nationalistiske partier og bevægelser. Og i takt med at disse voksede til mellem 10-20 pct. af vælgerskaren i lande som Holland, Frankrig, Polen og Danmark, reagerede flere og flere etablerede europæiske partier ved at overtage dette fokus for at undgå vælgertab og opnå genvalg. Denne strategi havde dog den modsatte effekt og legitimerede både EU-skepsissen og den indvandringsfjendske dagsorden yderligere, hvorfor de nynationalistiske partier fortsatte væksten bl.a. med større repræsentation i Europa-Parlamentet til følge.

På fælleseuropæisk plan fik RIA-rådet større politisk magt end Europa-Kommissionen, hvilket førte til blokeringen af fælleseuropæiske asyltiltag som omfordeling eller EU-genbosættelses-programmer. I forsøget på trods denne modstand at sikre den videre fælleseuropæiske integration udviklede også Kommissionen en tendens til at 'give noget på grænsekontrol' for at få medlemslandene med sig. Dette førte en række initiativer med sig blandt andet oprettelsen af Frontex agenturet i 2004 og udsendelser af tekniske missioner til Libyen fra både Kommissionen (2004) og Frontex (2007) med henblik på at etablere grænsekontrols-samarbejde med Muammar Gaddafis regime.

Samtidig blev Dublin-forordningen systematiseret, hvorved nordvestlige medlemslande som Danmark, Holland og Sverige kunne deportere asylansøgere tilbage til Unionens sydøstlige medlemslande, der i altovervejende grad var første ankomstlande og derfor havde al ansvaret for både grænsekontrol, asylsagsbehandling og integration. Dette satte lande som Grækenland og Italien under et enormt pres, men deres klager over et usolidarisk EU blev ignoreret. I samme periode implementerede EU også transportøransvar for flyselskaber, således at disse fik store 
Kommissionen brugte også grænsekontrol som et nyttigt redskab til at vise politisk handlekraft, men ligesom i medlemslandene betød det, at den politiske vilje til at planlægge modtagelsen af flere asylansøgere, en retfærdig omfordeling af disse medlemslandene imellem og pilotprojekter for etablering af lovlige og sikre flugtkanaler for mennesker fra konfliktområder blev afvist.

bøder, hvis asylansøgere nåede til Europa gennem deres tjenester.

Resultatet af denne økonomiske incitament-struktur blev, at selskaberne overtog grænsekontrollen fra staterne og begyndte at afskære flygtninge fra at benytte deres ruter. Dette betød omvendt, at 00'erne også blev vidne til et uhørt boom i smuglerindustrien, fordi irregulære ruter uden for staters kontrol nu reelt var blevet den eneste måde, hvorpå flygtninge og andre migranter kunne ankomme til EU. Kommissionen brugte altså også grænsekontrol som et nyttigt redskab til at vise politisk handlekraft og sikre fælles fodslag med RIA-rådet og medlemslandene.

Men ligesom i medlemslandene betød det, at den politiske vilje til at planlægge modtagelsen af flere asylansøgere, en retfærdig omfordeling af disse medlemslandene imellem samt pilotprojekter for etablering af lovlige og sikre flugtkanaler for mennesker fra konfliktområder blev afvist eller ikke støttet nok, når de mødte modstand fra RIA-rådet.

Alt imens blev fokusset på at forhindre asylansøgere adgang til Europa udbygget. Der oprettedes lejre i Gaddafis Libyen, men disse gav dog ikke folk adgang til beskyttelse i Libyen, der slet ikke anerkendte Flygtningekonventionen, og da slet ikke i europæiske lande. Tværtimod, samarbejdet med Libyen blev starten på et kontrolregime, der hurtigt blev kendt som umådeligt brutalt. Alt sammen hjulpet af økonomisk og politisk EU-støtte. I 2002 skrev det danske EU-formandskab ved udenrigsminister Per Stig Møller således, at et samarbejde med Libyen var både 'presserende' og 'essentielt'. Mellem 2006 og 2008 kanaliserede Aeneas-programmet millioner af euro til ti grænsekontrolprojekter i Libyen inkluderende containere, der blev brugt til at transportere flygtninge i dagevis gennem Sahara, og til 'Across Sahara I+II'-projekterne, hvis mål var at forhindre asylansøgere $\mathrm{i}$ at nå til Italien.

Især den daværende tyske regering støttede op om denne politik, og dens indenrigsminister, Otto Schily, havde talt så varmt for 'den libyske løsning' på EU's flygtningeproblem, at planen også var kendt som 'Schily-forslaget'. Den påvirkede sågar også Unionens udenrigspolitik under det arabiske forår: Gaddafi var blevet så afgørende en allieret for Unionens migrationspolitik, at kommissærerne Malmström og Fühle så sent som i oktober 2010 rejste til Tripoli og lovede Gaddafi 60 millioner euro for at fortsætte samarbejdet. En ganske uheldig timing taget $\mathrm{i}$ betragtning af, at Gaddafi få måneder senere havde fået tilskrevet rollen som menneskerettighedskrænkende despot, der fortjente NATOs bombardementer.

\section{Udenrigspolitik og eksternalisering}

EU-samarbejdet med Gaddafi er et glimrende eksempel på eksternaliseringen af grænsekontrol. Dette sker når stater (eller her EU) eksporterer dele af deres grænsekontrol udover eget territorium til andre stater. Rationalet er præventivt: Ved at rykke kontrollen længere væk fra egne grænser hindres flere asylansøgere i at drage nytte af landets asylsystem. Derved afskæres deres ret til at søge asyl, mens staten kan blive ved med at holde skål- 
taler om asylsystemets fortræffeligheder. Eksempler inkluderer både Dublin-forordningens bestemmelser af Grækenland og Italien som første ankomstlande, hvilket forvandlede dem til yderposter for resten af EU-medlemslandene, men altså også EU's samarbejde med repressive stater som Marokko, Libyen og fra slut-00'erne også Tyrkiet.

Typisk indgås sådanne aftaler gennem forhandlinger, hvor asylpolitik og grænsekontrol betinges af andre emner såsom energi-, transport og handels- eller militærpolitik. EU valgte at støtte Marokko med store summer for at oprette avancerede radarsystemer som SIVE og det Aeneas-sponserede Seahorse Network, alt imens Unionen så bort fra dens egen politik vedrørende Marokkos årtier lange besættelse af Vestsahara. Hvad angik Libyen, gav man grønt lys til at ophæve EU's våbenembargo mod Gaddafis regime, hvorefter adskillige medlemslande eksporterede overvågnings- og militærudstyr for hundredvis af millioner euro, til trods for at hans undertrykkelse af politiske modstandere var yderst velkendt.

Eksternalisering af grænsekontrol illustrerer derfor én måde, hvorved asylpolitik kan være knyttet til den udenrigspolitiske sfære. I princippet kunne EU prioritere menneskerettigheder lige så højt som ønskerne om at undgå asylansøgninger eller sikre eksportmarkeder for militært isenkram. Alternative links mellem asylpolitik og udenrigspolitik kunne således inkludere udviklingsstøtte, opbygning af asylsystemer eller forhandlinger med tredjelande om genbosættelse og omfordeling af flygtninge. Men mens der er nogle eksempler på EU-initiativer inden for støtte og udbygning af andre landes asylsystemer, har Unionen endnu ikke været leveringsdygtig, når det kommer til skabelsen af lovlige ruter for flygtninge til Europa eller mere ligelig modtagelse af dem medlemslandene imellem.

Henover sommeren 2015 kom der nye toner bl.a. med Europa-Kommissionens forslag om en omfordelingspolitik. Men den umådeligt langsomme implementering af Europa-Kommissionens septemberforslag om fordelingen af 120.000 flygtninge tyder på, at Unionen tog dette skridt for sent. Derved har den indenrigspolitiske comme il faut om at undgå asylansøgere efterladt det fælleseuropæiske projekt så vingeskudt, at det ifølge den tyske kansler Merkel overstiger Unionens alvorlige økonomiske krise.

\section{Fra libysk til tyrkisk løsning}

Efter kollapset af Schengen-rummets ydre grænser i efteråret 2015 har vi set implementeringen af en plan for samarbejde med Tyrkiet, der til forveksling ligner 'den libyske løsning. I november 2015, efter kansler Angela Merkels kontroversielle besøg hos AKP-regeringen i Istanbul en uge før det tyrkiske parlamentsvalg og kort tid efter bombningen af det tyrkiske oppositionsparti HDP's delegation under en fredsmarch i Ankara, blev der holdt et topmøde mellem EU og Tyrkiet på Malta. Her blev det aftalt, at EU skulle betale tre milliarder euro til Tyrkiet for at sikre de 2,4 millioner syriske flygtninge på tyrkisk territorium beskyttelse. Derudover lovede Tyrkiet fremover at 'sætte ind' over for flygtninge, der søger mod Grækenland.

Men denne 'tyrkiske løsning' lider af flere af de samme problemer som samarbejdet med Libyen gjorde - primært at EU synes villig til at se gennem fingre med brutalitet og korruption, så længe man undgår asylansøgere på europæisk jord. Allerede en halv måned efter at aftalen officielt blev indgået, udgav Amnesty In- 
ternational en rapport med alvorlige beskyldninger om, at aftalen reelt betød, at tyrkiske grænsevagter og politi indfanger, isolationsfængsler og tæsker flygtninge og tvangsdeporterer dem tilbage til krigszoner i Irak og Syrien.

Historien ser altså ud til at gentage sig nu med Tyrkiet i Libyens rolle. Som det også var tilfældet med samarbejdet med Gaddafi, skaber den indenrigspolitiske dagsorden i EU's medlemslande samt Europa-Kommissionens frygt for det europæiske samarbejdes fremtid en fundamental svaghed i EU's udenrigspolitik, der gør tredjelande i stand til at bruge EU's frygt for asylansøgninger til at lægge politisk og økonomisk pres på Unionen.

Men EU's politik har især også voldsomme konsekvenser for flygtninge, og dette bringer os tilbage til det humanitære aspekt af, hvorfor Fort Europa-analogien er utilstrækkelig. Betragter vi Unionens flygtningepolitik - først gennem eksternalisering og derefter gennem fordrivelse internt i Europa - bliver det tydeligt, at politikken producerer en helt speciel slags fordrivelse, nemlig hvad vi kan kalde grænseskabt fordrivelse.

\section{Grænseskabt fordrivelse}

Cirkulationen af beskyttelsesløse flygtninge er ikke noget nyt fænomen for Europa. Flygtningekonventionen var et resultat af de europæiske landes svigt over for jødiske flygtninge i 1930-40'erne, og i 197080’erne søgte europæiske stater også at afvise flygtninge uden at tillade asylansøgninger, hvilket blev kaldt 'flygtninge i kredsløb?

Efter Dublinkonventionen, transportøransvaret og udbygningen af europæisk grænsekontrol i 1990'erne og 00'erne blev denne cirkulation så skubbet ud i irregulære ruter gennem Unionens nabolande.
Ingen af disse var indstillet på at huse alle Europas uønskede flygtninge, og de indførte derfor, én efter én, mere grænsekontrol og flere deportationer. Flygtningene blev med andre ord reduceret til kastebolde i EU's grænseregioner.

Derved skabtes flygtningenes grænseskabte fordrivelse, en fordrivelse der skabes af de grænsesystemer, der skulle modtage og beskytte folk på flugt. Så europæisk grænsekontrol skal derfor ikke blot forstås som staters reaktion på folks tvungne migration forårsaget af $\mathrm{fx}$ konflikter, miljøkatastrofer eller udviklingsprojekter. Nej, grænsekontrollen skal også i sig selv ses som en årsag til flygtninges fordrivelse, og praksisserne bag den er motiveret af ønsket om ikke at tage ansvar for asylansøgere. Når mennesker på flugt fra krig og forfølgelse bliver tilbageholdt af grænsevagter, deporteret og transporteret mellem lejre og lande, er det altså en sekundær fordrivelse af allerede fordrevne mennesker.

Eksternaliseringens grænseskabte fordrivelse finder sted langt væk fra den europæiske offentligheds øjne. Flygtninge er blevet efterladt i den marokkanske ørken eller i Atlas-bjergene, har fået frastjålet alt og er blevet sendt ud i den libyske ørken eller er blevet kidnappet og tvunget til at afkræve løsepenge fra familie i Sinai-ørkenen, hvor også organtyveri fra flygtninge er udbredt. Grænseskabt fordrivelse er livsfarligt, og der har berettiget været megen europæisk fokus på de over 25.000 dødsfald ved EU's grænser siden 1993. Dertil skal lægges den grænseskabte fordrivelse uden for det israelske kontrolsystem, hvor mere end 4.000 flygtninge blev tortureret til døde i lejre opereret i samarbejde mellem smuglere og politi i Sinai-ørkenen.

Men de menneskelige omkostninger 
ל)

Da billedet af den lille druknede dreng Aylan Kurdi gik verden rundt, sendte det chokbølger gennem Europa, men selvom langt over 100 flygtningebørn siden da er druknet på tilsvarende vis, er politikernes modsvar udeblevet. ved denne form for fordrivelse kan ikke blot reduceres til døden. For dens primære karakteristik er den tvungne mobilitet. Før de ydre Schengen-grænser kollapsede i 2015, var det således normalt, at flygtninge brugte 5-7 forsøg på at nå til Italien fra Libyen. Den gængse flugt kunne derfor tage måneder og ofte år. Tidsrum der blev brugt i yderst sårbare omstændigheder især for de svageste grupper af flygtninge såsom uledsagede mindreårige $\mathrm{og}$ kvinder, der lever på smugleres eller politis nåde.

Når det kommer til flygtninge placeret i den grænseskabte fordrivelse uden for EU's grænser, antog tortur, voldtægter og tvangsarbejde et nærmest epidemisk omfang. Disse forhold var ikke ukendte for EU og blev kontinuerligt dokumenteret i rapporter fra Amnesty International, Læger Uden Grænser, Human Rights Watch og Dansk Flygtningehjælp.

Efter de ydre Schengen-grænsers kollaps er den grænseskabte fordrivelse og cirkulation af flygtninge nu drevet ind på kontinentet, og de europæiske befolkninger bevidner, hvad Unionen i deres navn har produceret uden for Europa. Denne fordrivelse internt i Europa forstærkes af de enkelte landes forsøg på at sende ansvaret videre til andre, hvilket har ført til en art domino-effekt: Først ledte Serbien flygtninge videre, så Ungarn, så Kroatien, så Slovenien, så Østrig, så Tyskland, så Danmark, så Sverige. Og i takt med at grænserne lukkes, forværres flygtningenes situation og deres muligheder.

2015 blev året, hvor den grænseskabte fordrivelse vendte tilbage til det Europa, der var med til at skabe den uden for sit eget territorium. Foreløbig har den ikke udviklet sig lige så brutalt som uden for Unionens grænser, og måske vil den europæiske offentlighed heller ikke acceptere dette. Men der er ovehængende risiko for, at den fortsatte mangel på fælles løsninger og medlemslandenes domino-lukning af grænserne både vil eskalere og normalisere fordrivelsen. Dette kan føre til en stiltiende accept af de inhumane konsekvenser af den grænseskabte fordrivelse.

Da billedet af den lille druknede dreng Aylan Kurdi gik verden rundt, sendte det chokbølger gennem Europa, men selvom langt over 100 flygtningebørn siden da er druknet på tilsvarende vis, er politikernes modsvar udeblevet. EU's dysfunktionelle asylpolitik har undermineret behovet for at adressere den bæredygtige modtagelse af flygtninge og de grundlæggende årsager til folks flugt, mens tid var. Og nu risikerer Unionen, der befinder sig i sin hidtil største krise, at se magtesløst til, mens medlemslandende ét for ét fremmaner forfærdelige genfærd fra Europas egen nære fortid. 